\title{
The role of macrophytes in the study of north-eastern Ladoga small island lakes evolution during the Holocene
}

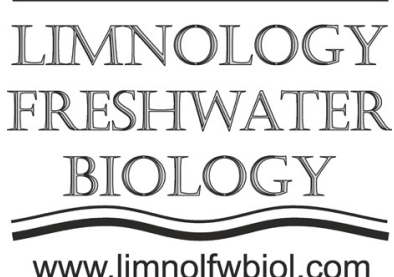

\author{
Gazizova T.Yu. ${ }^{1 *}$, Sapelko T.V. ${ }^{2}$, Korneenkova N.Yu. ${ }^{2}$ \\ ${ }^{1}$ Saint Petersburg State University, 13B University Emb., Saint-Petersburg, 199034, Russia \\ ${ }^{2}$ Institute of Limnology Russian Academy of Sciences, 9, Sevastyanova str., Saint-Petersburg, 196105, Russia
}

\begin{abstract}
The study of small lakes isolation process from a larger lake, Lake Ladoga, is both for studying the evolution of these lakes and changes of the Ladoga level in the past. Lake sediments are an excellent archive for the reconstruction of vegetation and climatic conditions of a past time. The sediment sequence from small lakes in the Lunkulansaari Island (NE part of Lake Ladoga) were studied using a pollen and macrofossil analysis. In the analysis, we are especially focused on aquatic plants, because water vegetation is directly related to the reservoirs dynamics. The correlation between the macrophytes dynamics and the reservoirs evolution stages is revealed. We reconstructed isolation small lakes of Lunkulansaari Island from Lake Ladoga using macrophyte analysis.
\end{abstract}

Keywords: Lake Ladoga, Holocene, lake sediments, macrophytes, pollen, macrofossil

\section{Introduction}

The Lunkulansaari Island is stretched from north-west to south-east in the north-eastern part of Ladoga. Its length is about $17 \mathrm{~km}$ and the maximum width of about $4 \mathrm{~km}$. Many researchers paid attention to macrophytes and used them in reconstructions of the paleoenvironmental (Taavitsainen et al., 1994; Saarnisto, Vuorela, 1998). The distribution of macrophytes in Lake Ladoga in the modern period has been studied by I.M. Raspopov. He also described the dynamics of higher aquatic vegetation in the modern period for the north-east coast, where the Lunkulansaari Island is located (Raspopov, 1968). Chenges in the island vegetation in the Ladoga area have been studied with existing pollen reconstructions in the Mantsinsaari Island (Delusin, Donner, 1995), Putsaary Island (Sapelko et al., 2014), Valaam Island (Saarnisto, 2012) and Kilpolansaari Island (Taavitsainen et al., 1994). However, special studies of macrophytes from lake sediments have not been conducted.

For the first time in paleolimnological studies we focused on the dynamics of macrophytes pollen and their macrofossil from sediment sequences of small lakes of the Lunkulansaari Island.

\section{Material and methods}

Three small lakes of the Lunkulansaari Island were sampled by the Institute of Limlology RAS in summer 2017 (Sapelko et al., 2018). The cores were obtained from Lakes Kuikkalampi (17 m a.s.l.), Sokkasenlampi (14 $\mathrm{m}$ a.s.l.) and Hovatanlampi (10 $\mathrm{m}$ a.s.l.). The cores were taken using a Russian corer. In addition, during the period of field research, geobotanical descriptions were performed. The sequences of lake sediments were studied using pollen and macrofossil analyzes.

\section{Results}

We reconstructed spruce and pine forests in the Lunkulansaari Island; pine forests with spruce and birch currently dominate. Overall trend in the natural environment dynamics are compared with existing pollen reconstructions for this area (Taavitsainen et al., 1994; Saarnisto, 2012). Based on pollen analysis, we found a diversity of aquatic vegetation (Nuphar, Nymphaea, Sparganium, Potamogeton, Alisma, etc.) at the beginning of sedimentation. In following, all macrophytes temporarily almost completely disappeared from the pollen spectrum and appear again with a different abundance and taxa diversity for each lake. The period of an absence of aquatic plants was also observed in other lake sediment sequences (Delusin, Donner, 1995; Saarnisto, 2012; Sapelko et al., 2018a). Based on the macrophytes dynamics in the Lunkulansaari Island lakes and analysis of other lakes data, we reconstructed three stages in lakes and paleoenvironment development in the North Ladoga area.

At the first stage, the Lunkulansaari Island was covered by Lake Ladoga. It was gulf with a diversify 
aquatic vegetation. At the second stage, Lakes Kuikkalampi, Sokkasenlampi and Hovatanlampi were sequentially isolated due to a dramatic drop of the Ladoga level. The isolation was fixed by the temporary disappearance of almost all macrophytes. At the third stage, the formation of their own aquatic vegetation occurred in these isolated lakes. Thus, overgrowing and bogging processes increased. In the present, the lakes are shallow (up to 3 meters). According to the botanical analysis, the lake waterlogging areas are at the stages of mesotrophic in Lake Sokkasenlampi and eutrophic in Lake Kuikkalampi communities now.

\section{Conclusions}

Based on our research, we revealed a correlation between the macrophytes dynamics and the small lake evolution stages. The results allowed us to refine a picture of the isolation Lunkulansaari Island small lakes from Lake Ladoga.

\section{Acknowledgements}

The study was carried out within the framework of the State Research Program of the Institute of Limnology, RAS No. 0154-2019-0001.

\section{References}

Delusin I., Donner J. 1995. Additional evidence of the Holocene transgression in Lake Ladoga on the basis of an investigation of the beach deposits on the island of Mantsinsaari. Bulletin of the Geological Society of Finland, pp. 39-50.

Raspopov I.M. 1968. Higher aquatic vegetation of Lake Ladoga. Plant resources of Lake Ladoga. Leningrad, pp. 16-72. (in Russian).

Saarnisto M. 2012. Late Holocene land uplift/neotectonics on the island of Valamo (Valaam), Lake Ladoga, NW Russia. Quaternary International 260: 143-152.

Saarnisto M., Vuorela I. 1998. Interpreting settlement indicators from sediments of a tundra lake: A Holocene pollen diagram from the northern coast of the Kola Peninsula. Paleoecological investigation of fresh water ecosystems, Apatity. Abstracts. P. 53.

Sapelko T.V., Terekhov A.V., Amantov A.V. 2018a. Ladoga transgression: reconstruction of the final stage and subsequent decline in the Northern part of the lake. Regional Geology and metallogeny 75: 23-34. (in Russian)

Sapelko T.V., Terekhov A.V., Gazizova T.Yu. et al. 2018. Paleolimnology of Lunkulansaari Island, Lake Ladoga: preliminary results. In: International conference "Freshwater ecosystems - modern challenges", September 10-14, Irkutsk. Abstracts of reports and poster messages, pp. 295-296.

Taavitsainen J.-P., Ikonen L., Saksa A. 1994. On early agriculture in the archipelago of Lake Ladoga. FefllWscondia orcJaaeologico Xl. pp. 29-39. 